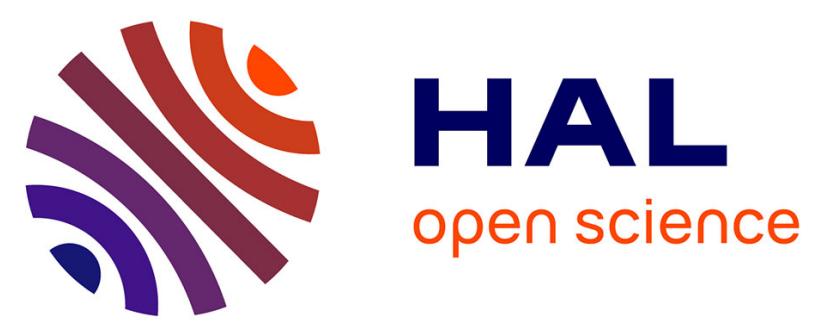

\title{
Lowering the applied potential during successive scratching/re-inoculation improves the performance of microbial anodes for microbial fuel cells
}

Stephanie F. Ketep, Alain Bergel, Marie Bertrand-Huleux, Wafa Achouak, Eric Fourest

\section{To cite this version:}

Stephanie F. Ketep, Alain Bergel, Marie Bertrand-Huleux, Wafa Achouak, Eric Fourest. Lowering the applied potential during successive scratching/re-inoculation improves the performance of microbial anodes for microbial fuel cells. Bioresource Technology, 2013, vol. 127, pp. 448-455. 10.1016/j.biortech.2012.09.008 . hal-00877380

\author{
HAL Id: hal-00877380 \\ https://hal.science/hal-00877380
}

Submitted on 28 Oct 2013

HAL is a multi-disciplinary open access archive for the deposit and dissemination of scientific research documents, whether they are published or not. The documents may come from teaching and research institutions in France or abroad, or from public or private research centers.
L'archive ouverte pluridisciplinaire HAL, est destinée au dépôt et à la diffusion de documents scientifiques de niveau recherche, publiés ou non, émanant des établissements d'enseignement et de recherche français ou étrangers, des laboratoires publics ou privés. 


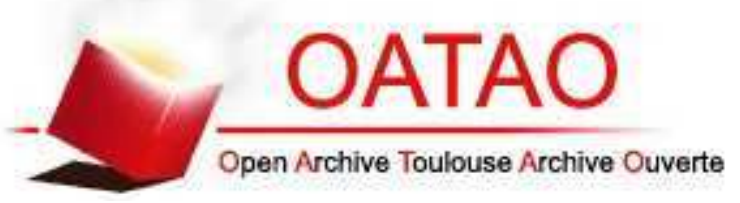

\section{Open Archive TOULOUSE Archive Ouverte (OATAO)}

OATAO is an open access repository that collects the work of Toulouse researchers and makes it freely available over the web where possible.

This is an author-deposited version published in : http://oatao.univ-toulouse.fr/ Eprints ID : 9932

To link to this article : DOI:10.1016/j.biortech.2012.09.008

URL : http://dx.doi.org/10.1016/j.biortech.2012.09.008

To cite this version : Ketep, Stephanie F. and Bergel, Alain and Bertrand, Marie and Achouak, Wafa and Fourest, Eric. Lowering the applied potential during successive scratching/reinoculation improves the performance of microbial anodes for microbial fuel cells. (2013) Bioresource Technology, vol. 127 . pp. 448-455. ISSN 0960-8524

Any correspondance concerning this service should be sent to the repository administrator: staff-oatao@ listes-diff.inp-toulouse.fr 


\title{
Lowering the applied potential during successive scratching/re-inoculation improves the performance of microbial anodes for microbial fuel cells
}

\author{
Stephanie F. Ketep ${ }^{\mathrm{a}, *}$, Alain Bergel ${ }^{\mathrm{b}}$, Marie Bertrand ${ }^{\mathrm{c}, \mathrm{d}}$, Wafa Achouak $^{\mathrm{c}, \mathrm{d}}$, Eric Fourest $^{\mathrm{a}}$ \\ ${ }^{a}$ Centre Technique du Papier, 341 rue de la papeterie, 38400 Saint Martin d'Hères, France \\ ${ }^{\mathrm{b}}$ Laboratoire de Génie Chimique CNRS, Université de Toulouse, 4 allée Emile Monso BP84234, 31432 Toulouse, France \\ ${ }^{\mathrm{C}} \mathrm{CEA}, \mathrm{DSV}, \mathrm{IBEB}$, Laboratoire d'Ecologie Microbienne de la Rhizosphere et Environnements extrêmes, 13108 Saint-Paul-lez-Durance, France \\ ${ }^{\mathrm{d}}$ CNRS, UMR 7265, Université Aix-Marseille, 13108 Saint-Paul-lez-Durance, France
}

H I G H L I G H T S

Lowering imposed potential with re-inoculations allow efficient bioanodes.

Alkaline $\mathrm{pH}$ up to 9.6 does not affect the efficiency of the anodes.

Desulfuromonas acetexigens was detected as dominant species.

Keywords:

Pulp mill effluent

Electroactive biofilm

Imposed potential

Alkaline $\mathrm{pH}$

Microbial fuel cell (MFC)

\begin{abstract}
A B S T R A C T
Microbial anodes were formed under polarisation at $-0.2 \mathrm{~V} / \mathrm{SCE}$ on smooth graphite plate electrodes with paper mill effluents. Primary, secondary and tertiary biofilms were formed by a successive scratching and re-inoculation procedure. The secondary and tertiary biofilms formed while decreasing the polarisation potential allowed the anodes to provide current density of $6 \mathrm{~A} / \mathrm{m}^{2}$ at $-0.4 \mathrm{~V} / \mathrm{SCE}$. In contrast, applying $-0.4 \mathrm{~V} / \mathrm{SCE}$ initially to form the primary biofilms did not lead to the production of current. Consequently, the scratching/re-inoculation procedure combined with progressive lowering of the applied potential revealed an efficient new procedure that gave efficient microbial anodes able to work at low potential. The observed progressive $\mathrm{pH}$ drift to alkaline values above 9 explained the open circuit potentials as low as $-0.6 \mathrm{~V} / \mathrm{SCE}$. The remarkable performance of the electrode at alkaline $\mathrm{pH}$ was attributed to the presence of Desulfuromonas acetexigens as the single dominant species in the tertiary microbial anodes.
\end{abstract}

\section{Introduction}

Strengthened environmental requirements and regulations have forced the pulp and paper industries to reduce the consumption of fresh water in papermaking processes. This trend has led to process waters that are highly concentrated in organic matter, requiring stronger treatment before the effluents can be rejected or recycled (Mathuriya and Sharma, 2009). Paper industries have consequently been searching for new effluent treatment technologies and, in this framework, microbial fuel cells (MFCs) might be a promising technology (Huang and Logan, 2008a). MFCs produce electrical energy from the oxidation of the organic matter contained in wastes. They could thus reduce the amount of sludge

\footnotetext{
* Corresponding author. Tel.: +33 476154348; fax: +33 476154016

E-mail address: francoise.ketep@ensiacet.fr (S.F. Ketep).
}

produced by biological treatment (Kim et al., 2007) and help to supply some of the energy needed by the treatment plant. At laboratory scale, MFCs have been shown to be able to treat effluents from various origins (Pant et al., 2009).

The objective of the present work was to design an optimal protocol for forming microbial anodes using an effluent coming from the pulp and paper industry. It has been shown that inoculating a reactor with a scraped-off biofilm collected from a running MFC (Rabaey et al., 2004; Kim et al., 2005; Wang et al., 2010; Harnisch et al., 2011; Cheng et al., 2011) or with the effluent from a previous reactor (Huang and Logan, 2008b) improves the electrochemical performance of the new biofilms with respect to the biofilms that were used as inoculum. Similarly, clean electrodes inserted in a running MFC in the vicinity of an already active biofilm anode have been shown to benefit from the presence of the already formed microbial anode (Liu et al., 2008).

Our protocol consisted of forming a primary biofilm from an inoculum source and then scratching the biofilm from the anode 
surface to use it to inoculate a new electrochemical cell. It now seems to be agreed that keeping the electrode polarised also favours the formation of efficient electroactive biofilms (Aelterman et al., 2008; Torres et al., 2009; Srikanth et al., 2010). An electrode potential can produce a selective pressure for bacterial evolution (Yi et al., 2009). The general target in designing microbial anodes is to obtain the highest possible current at the lowest possible potential. In this objective, it can be thought that polarising the electrode at low potential should favour the formation of efficient microbial anodes. This postulate has been validated by Torres et al. who have shown that anodes formed under low potential select the most efficient electrode-respiring bacteria (ERA). Anodes formed at $-0.15 \mathrm{~V}$ vs. SHE produced up to $8 \mathrm{~A} / \mathrm{m}^{2}$, while anodes formed in identical conditions at $+0.37 \mathrm{~V}$ gave no more than $0.6 \mathrm{~A} / \mathrm{m}^{2}$ (Torres et al., 2009).

Here, we tested an original procedure that combined the advantages of both re-inoculation and polarisation at low potential. Primary biofilms were formed from paper machine effluents. The primary biofilms were then scratched and used as inocula to form secondary biofilms and the operation was repeated for tertiary biofilms. The applied potential was reduced from $-0.2 \mathrm{~V} / \mathrm{SCE}$ for the formation of the primary biofilms to $-0.4 \mathrm{~V} / \mathrm{SCE}$ for the tertiary biofilms. To the best of our knowledge, such an association of scratching/re-inoculation steps with lowering potential is described for the first time here. The interest of the procedure was demonstrated by comparison with control experiments performed with an applied potential of $-0.4 \mathrm{~V} / \mathrm{SCE}$ for the formation of the primary biofilms, which did not succeed in producing current.

The successive biofilms were formed in the industrial effluent $(250 \mathrm{~mL})$, which was filtered at $0.3 \mu \mathrm{m}$ to remove planktonic microorganisms and supplemented with a synthetic medium $(200 \mathrm{~mL})$ to correct nutriment deficiencies, optimize the conditions for electroactive biofilm development, and stabilize the substrate supplied. The synthetic medium contained small amounts of carbonate, ammonium and phosphate compounds, potassium chloride and acetate. The small amounts of carbonate, ammonium and phosphate compounds did not have a significant buffer effect. In this condition the $\mathrm{pH}$ of the bulk was controlled by the evolution of the effluent itself.

Nitrogen and phosphate supplementation is commonly used to enhance the treatments of pulp and paper effluents. Acetate, provided by hydrolysis and acidogenesis of polysaccharides, is frequently observed in these effluents.

\section{Methods}

\subsection{Microbial inocula and synthetic medium}

Effluent samples were collected from the water circuits of a French newsprint production site. A first effluent sample was collected directly from the filtrates of the paper machine and was used as inoculum source for reactor A\#1. A second sample collected just after the primary clarification step of the waste water treatment plant was used similarly for reactor B\#1. Primary biofilms were formed with $250 \mathrm{~mL}$ of effluent supplemented with $200 \mathrm{~mL}$ of synthetic medium that contained $23.8 \mathrm{mM} \mathrm{NaHCO}$, $28 \mathrm{mM} \mathrm{NH}_{4} \mathrm{Cl}, 5 \mathrm{mM} \mathrm{NaH} \mathrm{PO}_{4}$ (pH 7.0) previously sterilized by autoclaving. $5 \mathrm{mM}$ sodium acetate and $10 \mathrm{mM} \mathrm{KCl}$ were added to the final solution (conductivity $3 \mathrm{mS} / \mathrm{cm}$ ). The secondary and tertiary biofilms were formed in identical mixtures but the effluent was previously filtered at $0.3 \mu \mathrm{m}$ to remove planktonic bacteria. The primary or secondary electroactive biofilms were detached from the electrode surfaces by ultrasound in $30 \mathrm{~mL}$ of physiological Ringer solution and this volume was used to inoculate the new electrochemical cell.

\subsection{Reactors and electrodes}

The electrochemical cells (borosilicate glass) contained $450 \mathrm{~mL}$ (primary biofilms) or $480 \mathrm{~mL}$ (secondary and tertiary biofilms) of solution with around $200 \mathrm{~mL}$ of headspace. The lid and the reactor body were sealed with a clamping ring. Working electrodes were flat $2 \mathrm{~cm} \times 5 \mathrm{~cm} \times 0.5 \mathrm{~cm}$ graphite plates (Goodfellow) screwed onto $2 \mathrm{~mm}$ diameter, $12 \mathrm{~cm}$ long titanium rods (Alfa Aesar) that ensured the electrical connection. Before use, the graphite electrodes were cleaned by $1 \mathrm{~h}$ of immersion in $1 \mathrm{M} \mathrm{HCl}, 20$ minutes' rinsing with distilled water and $1 \mathrm{~h}$ of immersion in $1 \mathrm{M} \mathrm{NaOH}$. Auxiliary electrodes were $90 \%$ Platinum-10\% Iridium grids (Heraeus), cleaned by heating in a blue flame. Potentials were controlled and expressed versus a saturated calomel electrode (SCE; potential $+0.24 \mathrm{~V}$ vs. SHE; Radiometer, Copenhagen). The reference electrode was as close as possible to the anode surface (working electrode) and the auxiliary electrode was in front of the anode, as far as possible from it.

\subsection{Electrochemical experiments}

Microbial anodes were formed at constant potential and characterized by chronoamperometry (CA) using a conventional threeelectrode set-up and a multi-channel potentiostat (model VMP3, software EC-Lab v 10.2, Bio-Logic SA). Current was recorded every $900 \mathrm{~s}$ and chronoamperometry was periodically suspended to record cyclic voltammetry (CV) curves at $1 \mathrm{mV} / \mathrm{s}$. The potential scan started at the potential imposed during CA to avoid damaging the biofilm. The primary biofilms were formed with the paper machine effluents in two parallel reactors (reactors $\mathrm{A} \# 1$ and $\mathrm{B} \# 1$ ) operated in strictly identical experimental conditions. The successive re-inoculations were then performed in strictly parallel ways without cross mixing from one reactor to the other. Temperature was maintained at $25^{\circ} \mathrm{C}$. Acetate ( 5 or $2.5 \mathrm{mM}$ ) was supplied repetitively to characterize the biofilms' maturation in optimal and reproducible conditions. When mentioned, the medium was gently sparged with $\mathrm{N}_{2}$. Coulombic efficiencies (CE) were calculated for each acetate addition as the ratio between the number of coulombs transferred to the anode and the maximum possible charge that the amount of added acetate could provide ( 8 electrons per acetate molecule). COD was titrated before each acetate addition. After one week, the COD in the effluent decreased from $1000-1200 \mathrm{mg} / \mathrm{L}$ to $300-350 \mathrm{mg} / \mathrm{L}$. This residual effluent COD corresponded to non-biodegradable organic substances. The organic substrate provided by the industrial effluents was thus considered negligible at this time and was not taken into account for the CE calculation.

\subsection{Microbial community analysis}

Microbial populations were analysed using 16SrDNA amplification followed by Denaturing Gradient Gel Electrophoresis (DGGE). Biofilms were scratched from the electrodes and bacterial DNA was extracted and stored at $-80^{\circ} \mathrm{C}$ before analysis. 16S rRNA gene fragments were amplified from extracted DNA using a nested PCR approach as described by Haichar et al. (2008). Briefly, the first PCR amplification step was performed using universal bacterial primers fD1 (5'-AGAGTTTGATCCTGGCTCAG-3', position 8-27 of the $E$. coli rrs gene), and S17 (5'-GTTACCTTGTTACGACTT-3'), position 1492-1509 of the E. coli rrs gene). For the second PCR step, PCR products were amplified using primers 375f-GC (Muyzer et al., 1993) and S10 (Table S1) to generate 584 bp products for DGGE analysis. Products were checked by electrophoresis in $2 \%$ agarose gels.

Denaturing gradient gel electrophoresis (DGGE) fingerprinting of PCR products was carried out using the Dcode Universal 
Mutation Detection System (BIO-Rad Laboratories, France) according to (Haichar et al., 2008). Certain bands of interest were excised and DNA was eluted and amplified. PCR products were sequenced at Genome express (Meylan, France) and sequences were analysed by the BLASTN search tool (Altschul et al., 1990) to determine sequence homology and to search for similar sequences in the GenBank database.

\section{Results and discussion}

\subsection{Primary, secondary and tertiary biofilms formed at lower applied potential}

Two primary biofilms were formed in parallel on graphite electrodes polarised at $-0.2 \mathrm{~V} / \mathrm{SCE}$ and immersed in $250 \mathrm{~mL}$ effluent from a papermaking unit mixed with $200 \mathrm{~mL}$ of low-concentration synthetic medium. The effluent collected from the filtrate of the paper machine water was used in reactor $A \# 1$ and the clarified waste water in reactor B\#1 (Fig. 1A). The current increased after an initial lag period of a few days as commonly observed for the formation of electroactive biofilm on polarised electrodes. The current then decreased due to acetate depletion and successive additions of $5 \mathrm{mM}$ acetate generated similar current peaks, which indicated that, from the point of view of electrochemical catalysis, the biofilms reached maturity with only two acetate additions. The two inoculum samples (effluent from the paper machine or after clarification) did not lead to any significant difference. Considering the second to fourth acetate additions, the maximum current densities provided were $5.5 \mathrm{~A} / \mathrm{m}^{2}$ on average ( 6 measurements from 3.8 to $6.8 \mathrm{~A} / \mathrm{m}^{2}$ ) and Coulombic efficiencies were from $11 \%$ to $22 \%$. The low Coulombic efficiencies could have been predicted by considering the experimental set-up chosen: a working electrode of small surface area $\left(10 \mathrm{~cm}^{2}\right)$ in a large volume of solution $(450 \mathrm{~mL})$. From a general point of view, these operating conditions minimize the effects of the variation in composition of the bulk solution due to the electrochemical reactions. A small surface area of the working electrode is optimal from the standpoint of electrochemical analysis but it obviously does not promote high coulombic efficiencies, particularly when homogeneous reactions occur, as was the case here.

The primary biofilms were removed from the anode surfaces and used to inoculate two new electrochemical reactors filled with $250 \mathrm{~mL}$ of filtered effluents and $200 \mathrm{~mL}$ of synthetic medium. Electrodes were polarised at $-0.2 \mathrm{~V} / \mathrm{SCE}$ (Fig. 1 , reactors $\mathrm{A \# 2}$ and $\mathrm{B \# 2}$ ). The initial lag period was reduced in comparison to the primary biofilms and performances until day 8 were similar to those of the primary biofilms. At day 8 , two effects were studied simultaneously: acetate addition was reduced from 5 to $2.5 \mathrm{mM}$ in both reactors, and reactor $\mathrm{B} \# 2$ was placed under continuous nitrogen bubbling. The reduction of acetate concentration did not decrease the current density, indicating that substrate was not limiting. In contrast, nitrogen bubbling in reactor $\mathrm{B} \# 2$ had a clear effect on $\mathrm{CE}$, which increased to $47 \%$, while reactor $\mathrm{B} \# 1$ remained at $21 \%$. Nitrogen bubbling clearly stabilized the $\mathrm{CE}$ at higher values. Nitrogen established anoxic conditions, which prevented the oxidation of acetate by aerobic bacteria in the bulk, resulting in lower competition against the anode respiring bacteria.

From day 11, the applied potential was changed to -0.3 and then $-0.4 \mathrm{~V} / \mathrm{SCE}$. The performance of both electrodes remained stable with a current density of $7.5+1 \mathrm{~A} / \mathrm{m}^{2}$ and CE of $40+2 \%$ for reactor $\mathrm{B} \# 2$ under $\mathrm{N}_{2}$ bubbling and a current density of $4.5+0.5 \mathrm{~A} / \mathrm{m}^{2}$ and CE $26+2 \%$ for reactor A\#2 not subjected to $\mathrm{N}_{2}$.

Secondary biofilms were used to inoculate third electrochemical reactors with a potential of $-0.4 \mathrm{~V} / \mathrm{SCE}$ applied from the start (Fig. 1, \#3). Acetate concentration was brought back to $5 \mathrm{mM}$ and
$\mathrm{N}_{2}$ was continuously bubbled into both reactors (A\#3 and B\#3). Both tertiary electrodes showed remarkable performance; they provided current densities in the 4.5 to $6.8 \mathrm{~A} / \mathrm{m}^{2}$ range ( 8 measurements) at a potential as low as $-0.4 \mathrm{~V} / \mathrm{SCE}$. After a 5-day deficiency of substrate, one anode showed a remarkable robustness by immediately recovering the same level of current when the substrate was provided again. However, in similar conditions the second anode recovered only around $50 \%$ of the current.

Finally, the formation of the two primary biofilms was attempted with the optimal conditions defined here, i.e. an applied potential of $-0.4 \mathrm{~V} / \mathrm{SCE}$ and continuous nitrogen bubbling. For the formation of primary biofilms, the $250 \mathrm{~mL}$ effluent samples, which served as inoculum sources, were obviously not filtered. No significant current was recorded after 28 days of polarisation and 4 successive additions of $5 \mathrm{mM}$ acetate (results not shown). Current density was always lower than $0.03 \mathrm{~A} / \mathrm{m}^{2}$ for both experiments. The potential of $-0.4 \mathrm{~V} / \mathrm{SCE}$ was consequently too low to allow microbial anodes to form directly from the raw effluents.

In summary, forming primary biofilms directly at $-0.4 \mathrm{~V} / \mathrm{SCE}$ did not produce current. Using primary biofilms formed at $-0.2 \mathrm{~V} / \mathrm{SCE}$ as inocula led to secondary biofilms that provided significant current when the potential was decrease to $-0.4 \mathrm{~V} /$ SCE. Finally, it was possible to form tertiary biofilms directly at $-0.4 \mathrm{~V} / \mathrm{SCE}$ using the secondary biofilms as inocula.

\subsection{Analysis of the catalytic cyclic voltammetry (CV)}

So-called catalytic voltammetry is voltammetry recorded when the substrate is present at a significant concentration in solution. The quality of the tertiary microbial anodes formed at $-0.4 \mathrm{~V} / \mathrm{SCE}$ can be assessed from the cyclic voltammetry (CV) curves recorded at day 11, when the current was maximal (CV1, Fig. 2, A\#3 and $B \# 3)$. On each CV curve, the current densities measured at $-0.4 \mathrm{~V} / \mathrm{SCE}$ (6.2 and $4.1 \mathrm{~A} / \mathrm{m}^{2}$ for reactors $\mathrm{A} \# 3$ and $\mathrm{B} \# 3$, respectively) were similar to the current densities obtained during chronoamperometry (6.8 and $4.5 \mathrm{~A} / \mathrm{m}^{2}$ for reactors A\#3 and $\mathrm{B} \# 3)$. The scan rate of $1 \mathrm{mV} / \mathrm{s}$ was consequently low enough to represent the stationary characteristics of the electrode. The voltammograms recorded in the absence of substrate (CV2, Fig. 2) confirmed that the current was due to acetate oxidation. The two $\mathrm{CV} 1$ plotted in Fig. 2 corresponded to the highest and lowest values of current $\left(6.8\right.$ and $4.5 \mathrm{~A} / \mathrm{m}^{2}$ ) recorded during the first two weeks of polarisation They exhibited some difference in electrochemical kinetics: the best anode (A\#3) was able to provide up to $13 \mathrm{~A} / \mathrm{m}^{2}$ at $0.0 \mathrm{~V} / \mathrm{SCE}$ (average of the values measured on the oxidation and reduction scans), while the other $\left(\mathrm{B} \# 3\right.$ ) reached only $5 \mathrm{~A} / \mathrm{m}^{2}$ at the same potential. Nevertheless, both anodes exhibited interesting performance at potential values as low as $-0.4 \mathrm{~V} / \mathrm{SCE}$.

The current densities obtained here were among the highest reported in the literature for comparable conditions. Obviously, higher values have been reported (for a review see Liu et al., 2010) but most of them have been obtained at higher temperature $\left(40^{\circ} \mathrm{C}\right.$, whereas experiments were performed here at $25^{\circ} \mathrm{C}$ ) or with three-dimensional electrodes (felts, brushes, granule beds, porous structures, etc.). For example, up to $30.8 \mathrm{~A} / \mathrm{m}^{2}$ (Chen et al., 2011) has been reached on three-dimensional fibre electrodes taking advantage of the optimal porosity of the electrode structure. Nevertheless, this current density expressed with respect to the projected surface area cannot be straightforwardly compared to the current density obtained here on smooth electrode surfaces. For instance, up to $66 \mathrm{~A} / \mathrm{m}^{2}$ has been reported with electroactive biofilms formed around ultra-microelectrodes (Pocaznoi et al., 2012). In this case, the particular electrochemical properties of the ultra-microelectrodes were responsible for the high current density obtained, but the same biofilms developed on conventional macro-sized electrodes gave current density of only $7 \mathrm{~A} / \mathrm{m}^{2}$. The maxima 
Reactors A
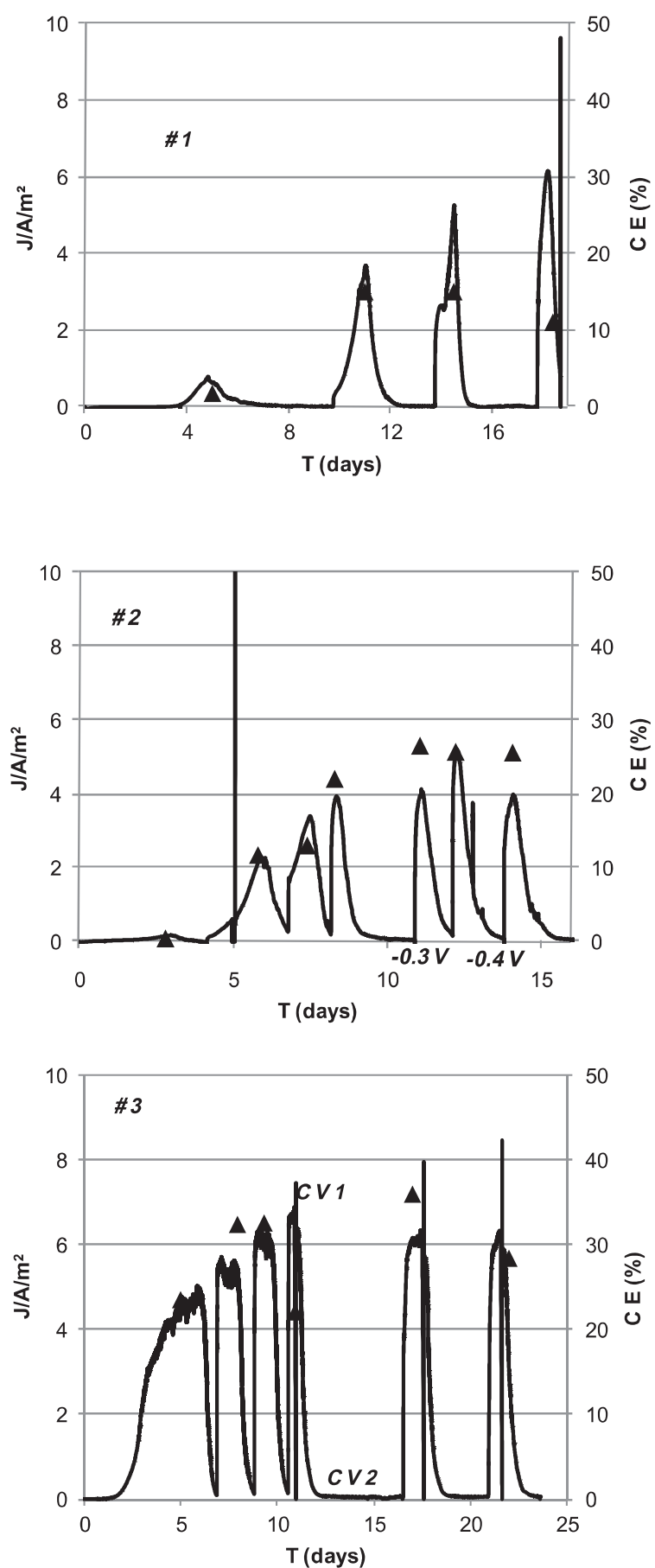

Reactors B
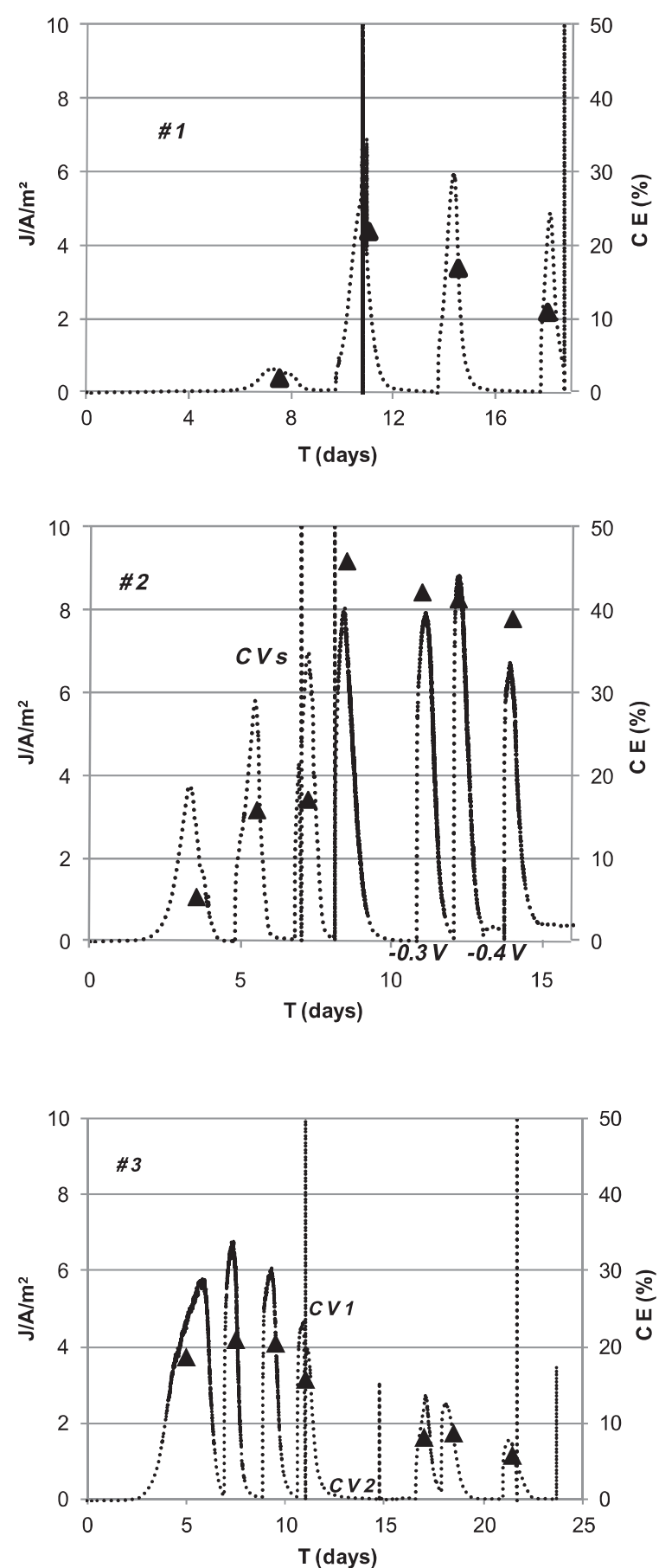

Fig. 1. Current density (lines, right $Y$-axis) and coulombic efficiencies (dots, left $Y$-axis) recorded during the formation of the primary, secondary and tertiary anodes, with additions of $5 \mathrm{mM}$ acetate. The initial source of microorganisms was the paper machine wastewater (reactors A, left column) or the same effluent after clarification (reactors $\mathrm{B}$, right column); (\#1) primary biofilms at $-0.2 \mathrm{~V} / \mathrm{SCE}$; (\#2) secondary biofilms initially at $-0.2 \mathrm{~V} / \mathrm{SCE}$, potential changes are indicated on the $X$-axis, $\mathrm{N}_{2}$ sparging was started in reactor $\mathrm{B} \# 2$ on day 8 ; acetate additions of $2.5 \mathrm{mM}$ from day 8 ; (\#3) tertiary biofilms at $-0.4 \mathrm{~V} / \mathrm{SCE}$ under $\mathrm{N}_{2}$ sparging in both reactors from the beginning.

obtained here, in the range 4.5 to $6.8 \mathrm{~A} / \mathrm{m}^{2}$ at $-0.4 \mathrm{~V} / \mathrm{SCE}$ ( 5 to $13 \mathrm{~A} / \mathrm{m}^{2}$ at $0.0 \mathrm{~V} / \mathrm{SCE}$ ) on flat graphite electrodes without any surface treatment and without enhanced roughness can be attributed to the remarkable electroactivity of the biofilms formed.

Comparison of the CV of the tertiary anode with the CV of the secondary biofilm formed at $-0.2 \mathrm{~V} / \mathrm{SCE}$ (CVs, Fig. 2) emphasized the improved quality of the tertiary anode. The secondary anode exhibited an open circuit potential of only $-0.48 \mathrm{~V} / \mathrm{SCE}$, while the tertiary anode open circuit potential was $-0.6 \mathrm{~V} / \mathrm{SCE}$. In consequence the secondary anode polarised at $-0.2 \mathrm{~V}$ in reactor $\mathrm{B} \# 2$ was able to produce less than $2 \mathrm{~A} / \mathrm{m}^{2}$ at $-0.4 \mathrm{~V} / \mathrm{SCE}$ on day 8 . Progressive reduction of the applied potential allowed this biofilm to produce up to $6 \mathrm{~A} / \mathrm{m}^{2}$. The procedure described here, of re-inoculating and concomitantly lowering the applied potential, clearly improved the electrochemical quality of the microbial anodes.

\section{3. $\mathrm{pH}$ evolution}

During the polarisation experiments, the $\mathrm{pH}$ of the media always varied towards higher values. For example, the $\mathrm{pH}$ evolution 

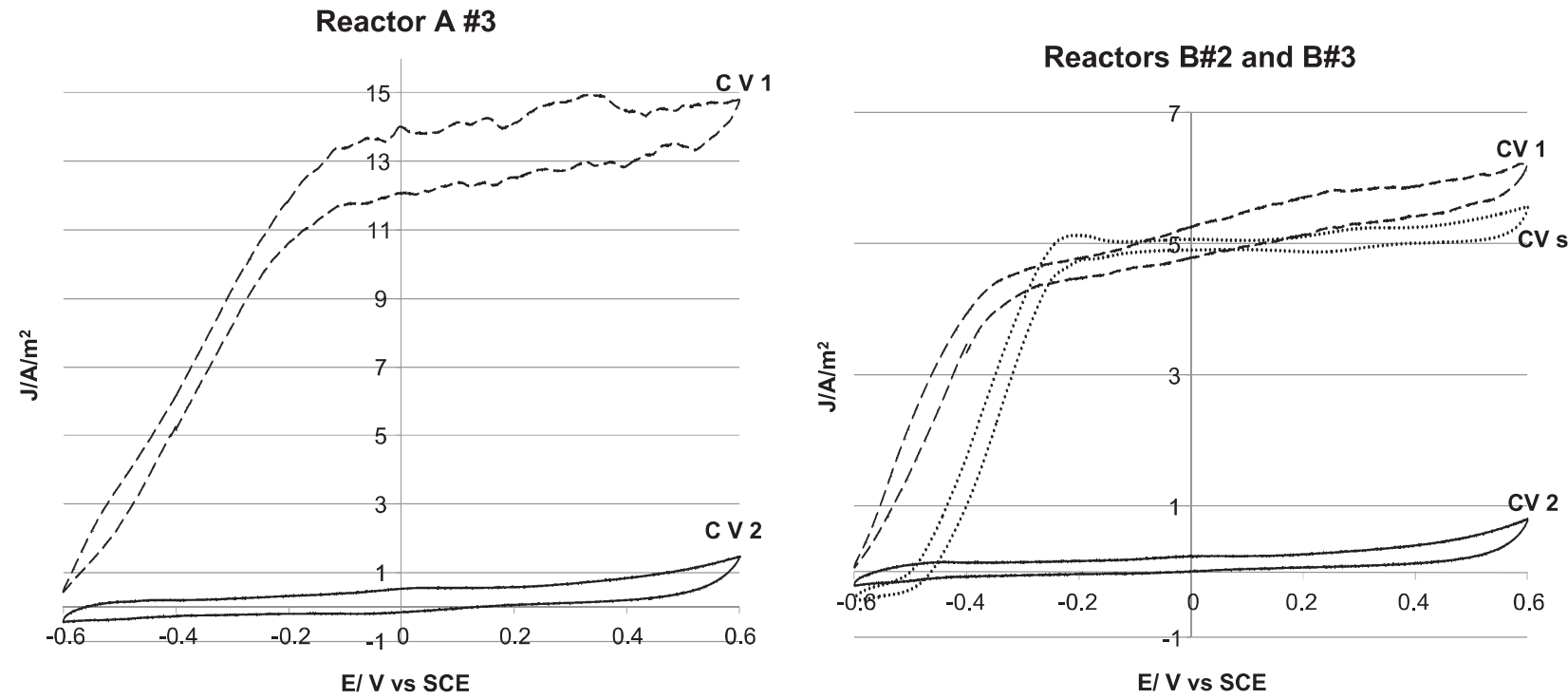

Fig. 2. Cyclic voltammograms at $1 \mathrm{mV} / \mathrm{s}$ with the tertiary electrodes: CV1 was recorded at day 11 , and CV2 at day 15 as indicated in Fig. 1 (reactors A\#3 and B\#3). CVs were recorded at day 8 with the secondary biofilm formed at $-0.2 \mathrm{~V} / \mathrm{SCE}$ in reactor $\mathrm{B} \# 2$.

during the secondary biofilm formation illustrated this general trend: the $\mathrm{pH}$ rose in similar way in both reactors from day 1 to day 5 (from 7.5 to 8.4 or 8.7 in reactors $A$ and B, respectively). Then the $\mathrm{pH}$ reached higher values in reactor $\mathrm{B}$, in which $\mathrm{N}_{2}$ bubbling was started at day 8 ( $\mathrm{pH}$ of 9.6 in B against 8.9 in A without $\mathrm{N}_{2}$ bubbling). The $\mathrm{pH}$ changed to alkaline values during each experiment and nitrogen bubbling increased the alkalinisation rate. The alkalinisation cannot be explained by the electrochemical reactions. Actually, the anode biofilm oxidised acetate into carbon dioxide

$\mathrm{CH}_{3} \mathrm{COO}^{-}+2 \mathrm{H}_{2} \mathrm{O} \rightarrow 8 \mathrm{e}^{-}+2 \mathrm{CO}_{2}+7 \mathrm{H}^{+}$

which hydrolysed into hydrogen carbonate:

$2 \mathrm{CO}_{2}+2 \mathrm{H}_{2} \mathrm{O} \rightarrow 2 \mathrm{HCO}_{3}^{-}+2 \mathrm{H}^{+}$

Combining Eqs. (1) and (2) leads to

$\mathrm{CH}_{3} \mathrm{COO}^{-}+4 \mathrm{H}_{2} \mathrm{O} \rightarrow 8 \mathrm{e}^{-}+2 \mathrm{HCO}_{2}^{-}+9 \mathrm{H}^{+}$

9 protons were produced per 8 electrons. In comparison, the cathode achieving the reduction of water in anoxic conditions

$8 \mathrm{H}_{2} \mathrm{O}+8 \mathrm{e}^{-} \rightarrow 4 \mathrm{H}_{2}+8 \mathrm{OH}^{-}$

or the reduction of oxygen in non-anoxic conditions

$2 \mathrm{O}_{2}+4 \mathrm{H}_{2} \mathrm{O}+8 \mathrm{e}^{-} \rightarrow 8 \mathrm{OH}^{-}$

produced 8 hydroxyl ions per 8 electrons. The electrochemical reactions globally contributed to a slight acidification of the medium ( 1 proton produced per 8 electrons). Consequently, alkalinisation of the bulk was not linked to the electrochemical reactions.

In order to confirm that the electrochemical reactions were not responsible for alkalinisation, experiments were performed in the absence of electrodes. The $\mathrm{pH}$ of the effluent/synthetic medium $(250 / 200 \mathrm{~mL})$ mixture was monitored in three parallel reactors that did not contain electrodes, under three different conditions: (i) without stirring and without $\mathrm{N}_{2}$ bubbling; (ii) with mechanical stirring and without $\mathrm{N}_{2}$ bubbling, and (iii) with $\mathrm{N}_{2}$ bubbling and without stirring.

$5 \mathrm{mM}$ acetate was added at days $0,5,8$ and 12 to remain close to the operating conditions of the polarisation experiments. The initial pH of 7.0 rose to alkaline values in each of the 3 reactors and stabilized after 15 days at $7.7+0.1,8.05+0.05$ and $8.9+0.1$ (average values between days 12 and 15 ) in reactors (i-iii), respectively. It was thus confirmed that alkalinisation was not due to the electrochemical reactions but occurred spontaneously in the effluent. Such a spontaneous $\mathrm{pH}$ drift has rarely been reported in the literature because studies have generally used buffered conditions. In contrast, alkalinisation was evidenced here because only minimal supplementation was used, which did not mask the real behaviour of the effluent during operation. The phosphate concentration of $2.2 \mathrm{mM}$ of added phosphate in the $(250 / 200 \mathrm{~mL})$ mixture could not have a significant buffer effect and could not maintain the $\mathrm{pH}$ at its initial neutral value.

The progressive $\mathrm{pH}$ drift to alkaline values observed under nitrogen bubbling and, to a lesser extent, mechanical stirring, are explained by the extraction of carbon dioxide from the solution. Removing carbon dioxide from the solution shifted the acid-base equilibrium of carbonate species:

$\mathrm{CO}_{2}+\mathrm{H}_{2} \mathrm{O} \leftrightarrow \mathrm{H}_{2} \mathrm{CO}_{3} \leftrightarrow \mathrm{HCO}_{3}^{-}+\mathrm{H}^{+} \quad$ pKa1 $=6.3$

$\mathrm{HCO}_{3}^{-}+\mathrm{H}_{2} \mathrm{O} \leftrightarrow \mathrm{CO}_{3}^{2-}+\mathrm{H}_{3} \mathrm{O}^{+} \quad$ pKa2 $=10.3$

towards alkalinisation. Obviously, $\mathrm{N}_{2}$ bubbling was more efficient that simple mechanical stirring with a magnetic barrel because $\mathrm{N}_{2}$ bubbling further reduced the partial $\mathrm{CO}_{2}$ pressure compared to stirring under atmospheric conditions.

Generally, bacteria require $\mathrm{pH}$ close to neutrality for optimal growth (Jadhav and Ghangrekar, 2009; Gil et al., 2003). In this work, $\mathrm{pH}$ reached values up to 9.5 at the end of the experiments with continuous $\mathrm{N}_{2}$ bubbling. Given the high current density obtained, it can be concluded that the microbial anodes were well suited to effluent alkalinisation. Actually, high $\mathrm{pH}$ values increase the standard potential of acetate, which is $-0.63 \mathrm{~V} / \mathrm{SCE}$ at $\mathrm{pH} 9.0$. The maximal Gibb's energy available for bacterial growth is proportional to the difference between electrode potential and the formal potential of the electron donor. The open circuit potential around $-0.60 \mathrm{~V} / \mathrm{SCE}$ observed on CV curves (Fig. 2), only $30 \mathrm{mV}$ above the formal potential of acetate oxidation, was a first mark of the high electrocatalytic ability of the anode respiring bacteria present in the biofilm. Moreover, under the applied potential of $-0.4 \mathrm{~V} / \mathrm{SCE}$ they were able to grow and transfer electrons to the electrode by exploiting a potential drop of only $230 \mathrm{mV}$.

A few studies have observed that MFCs can provide high current under alkaline conditions (Rozendal et al., 2008; Fan et al., 2007). An air-cathode MFC has been shown to tolerate a feed electrolyte having a $\mathrm{pH}$ of up to 10 , the highest current being reached at $\mathrm{pH} 9$ 


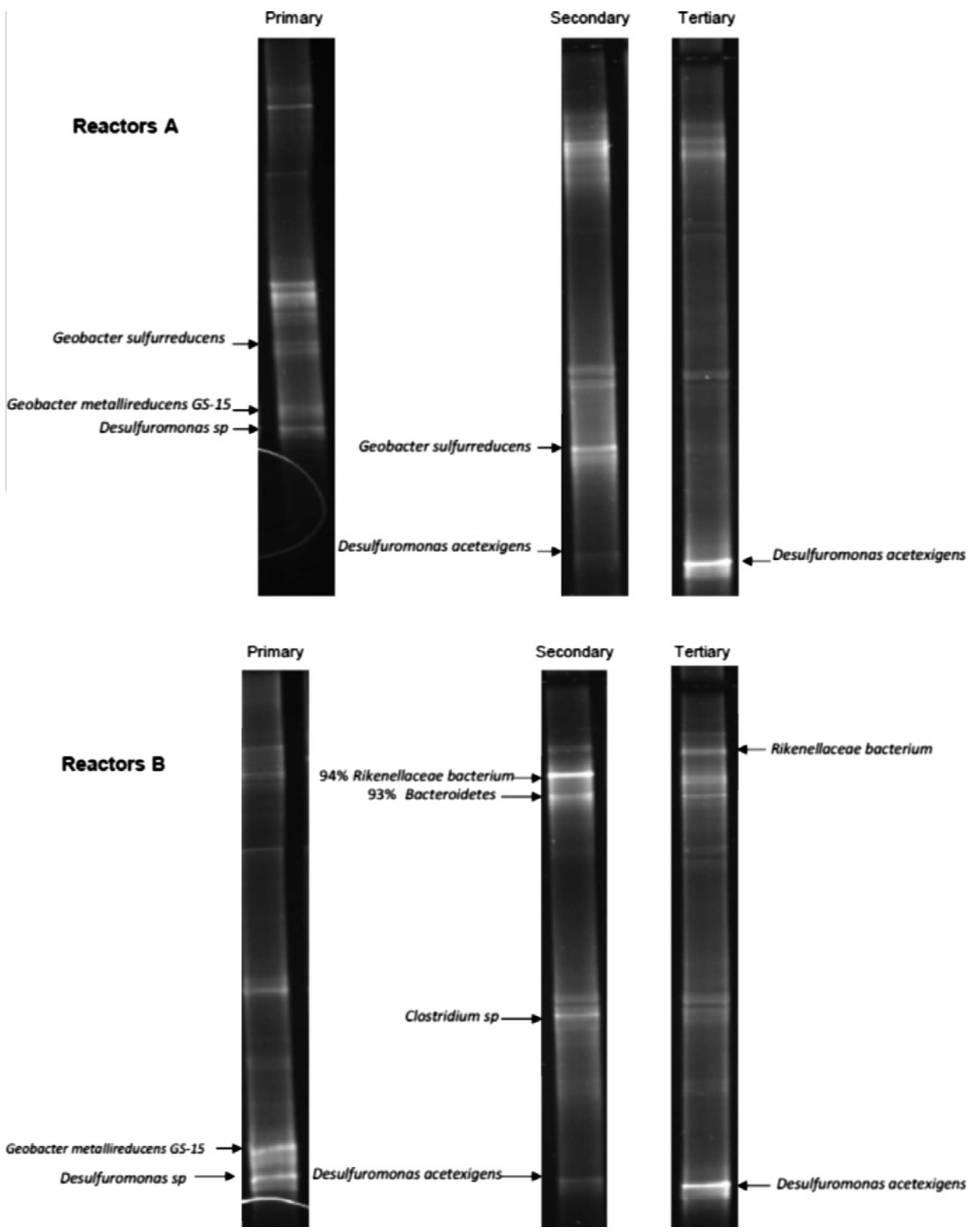

Fig. 3. Evolution of DGGE profiles based on $16 \mathrm{~S}$ rRNA genes PCR-amplified from bacteria forming primary, secondary and tertiary biofilms.

(He et al., 2008). Puig et al. (2010) have suggested that pH 9.5 may be considered optimal for an MFC to generate current from urban wastewaters (Puig et al., 2010). Zhuang et al. have shown that microorganisms can oxidise organic matter under highly alkaline conditions up to $\mathrm{pH} 10$ in an air-cathode two-chamber MFC (Zhuang et al., 2010). According to the results described in the present work, studies using unbuffered media should be favoured now because of their interest for operating microbial fuel cells without adding large amounts of buffering compounds.

3.4. Evolution of microbial community in primary, secondary and tertiary biofilms analysed by DGGE and non-turnover $C V$

DGGE analyses of microbial communities showed a drastic selection from the primary to tertiary biofilms with Geobacter metalireducens, Desulfuromonas sp. and Geobacter sulfureduccens as dominant species (Fig. 3). These bacteria are classically known to have anode respiring properties. They are able to implement the most efficient electron transfer pathways by direct electron transfer to the electrode without the need for a diffusible redox mediator (Logan, 2009). The potential of $-0.2 \mathrm{~V} / \mathrm{SCE}$ was consequently low enough to select to the most efficient anode respiring bacteria (Torres et al., 2009). No significant difference was observed between the two effluent samples before and after the clarification step.

The secondary biofilms showed remarkable modifications of the microbial populations with respect to the primary ones. Most Geobacter species no longer appeared among the dominant species (only Geobacter sulfurreducens remained in reactor A\#2), while other species identified as Bacteriodetes and Clostridium sp. emerged in reactor B\#2. These species have already been identified in electroactive biofilms formed from activated sludge (Torres 

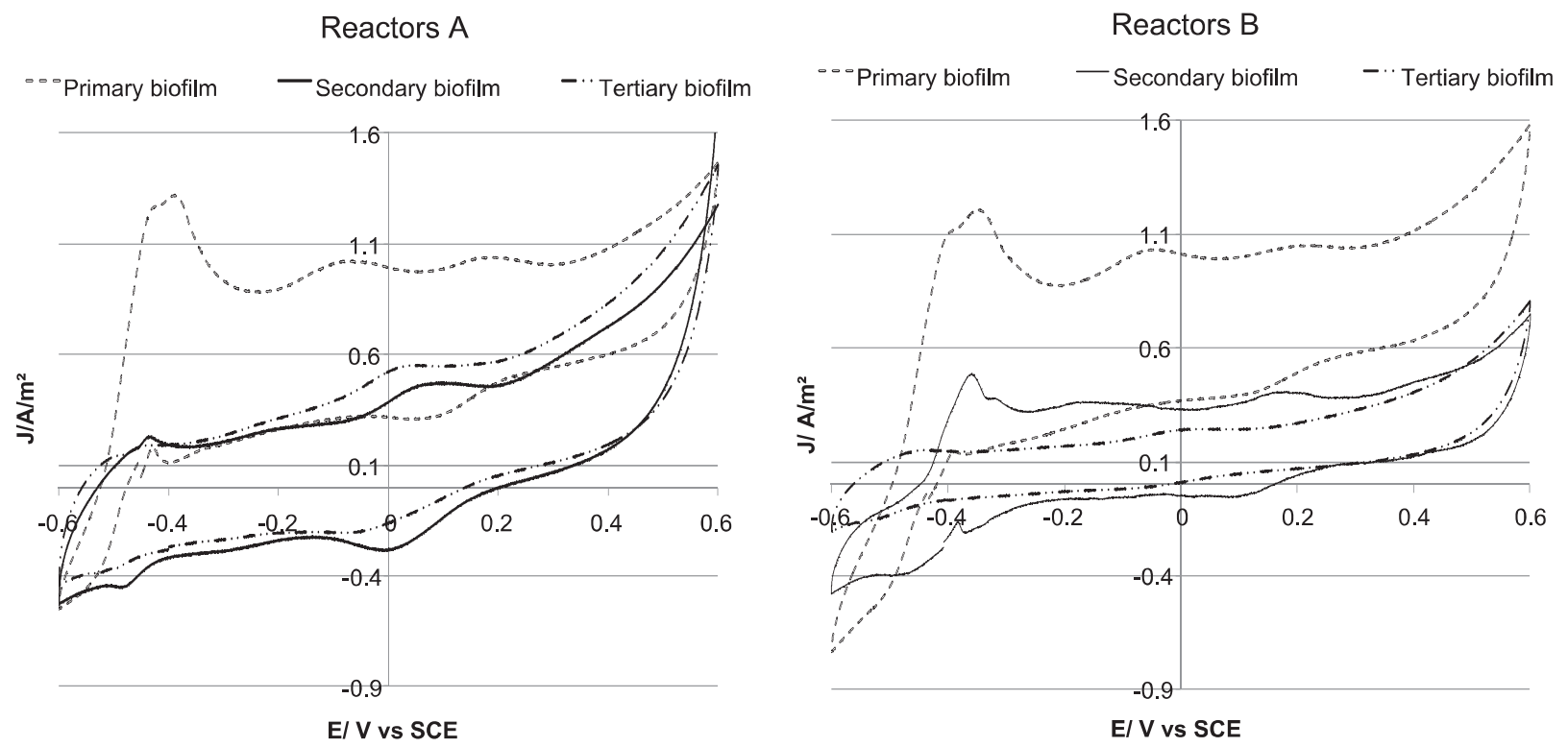

Fig. 4. Non-turn-over CVs performed at $1 \mathrm{mV} / \mathrm{s}$ recorded at the end of each polarisation period for reactors $\mathrm{A}$ and $\mathrm{B}$.

et al., 2009) and marine environments (Erable et al., 2009). From the secondary biofilms, a common band appeared which was present for both electrodes. This band corresponded to Desulfuromonas acetexigens, a bacterium described in 1994 as an obligate anaerobic sulphur-reducing eubacterium that exclusively used acetate as energy and carbon source (Finster et al., 1994). In the tertiary biofilms, Geobacter sp. were no longer detected and Desulfuromonas acetexigens was the single dominating species in both biofilms.

The negative selection of Geobacter $s p$. with re-inoculation was confirmed by the non-turnover $\mathrm{CV}$ recorded on primary, secondary and tertiary biofilms at the end of polarisation (Fig. 4). So-called non-turnover $\mathrm{CVs}$ are recorded when the substrate is depleted. They thus give a comprehensive view of the redox compounds contained in the biofilms that can be addressed by the electrode (Fricke et al., 2008; Harnisch and Freguia, 2012). The strong peaks around $-0.4 \mathrm{~V} / \mathrm{SCE}(-0.16 \mathrm{~V} / \mathrm{SHE})$ can be attributed to Geobacter $s p$. by comparison to the $\mathrm{CV}$ curves reported in the literature with pure culture of Geobacter sulfurreducens (Marsili et al., 2008). These peaks decreased from the primary to the secondary electrodes and disappeared completely from the tertiary electrodes. The low potential of $-0.4 \mathrm{~V} / \mathrm{SCE}$ to which the secondary biofilms were exposed (from day 11) and at which the tertiary biofilms were formed, was doubtless responsible for the vanishing of the Geobacter species from the microbial communities. Moreover, Geobacter $s p$. are known to have optimal growth around pH 6.8 (Fricke et al., 2008; Marsili et al., 2008) and the high pH values observed here would also have hindered their development. The electrochemical and DGGE analyses converged in showing that Geobacter disappeared from primary to secondary biofilms. This suggested that Desulfuromonas acetexigens was probably the bacterium responsible for the high current density obtained here with the tertiary electrodes at low potential and alkaline $\mathrm{pH}$. Nevertheless, the numerical abundance of bacteria in biofilms is not, a priori, correlated with the capacities of the predominant species for high power production (Kiely et al., 2011). Therefore, isolation and electrochemical testing of the isolate are needed to confirm this hypothesis.

\section{Conclusions}

The electroactive biofilms formed by successive scratching and re-inoculation steps while lowering applied potential provided high current density $\left(6 \mathrm{~A} / \mathrm{m}^{2}\right.$ on smooth electrode surfaces) at low potential $(-0.4 \mathrm{~V} / \mathrm{SCE})$ and alkaline $\mathrm{pH}$ (around 9 ), which is of great interest for operating microbial fuel cells from pulp and paper effluents without adding buffering compounds. Such biofilms could not be formed by applying low potential from the first step of primary biofilm formation. To our knowledge, this is the first time that such a procedure has been used and it may explain why Desulfuromonas acetexigens has not been identified before in electroactive biofilms.

\section{Acknowledgements}

This work was achieved in the framework of the "Agri-Elec (ANR-008-BioE-001)" project supported by the French National Research Agency (ANR).

\section{References}

Aelterman, P., Freguia, S., Keller, J., Verstraete, W., Rabaey, K., 2008. The anode potential regulates bacterial activity in microbial fuel cells. Appl. Microbiol. Biotechnol. 78, 409-418.

Altschul, S.F., Gish, W., Miller, W., Myers, E.W., Lipman, D.J., 1990. Basic local alignment search tool. J. Mol. Biol. 215, 403-410.

Chen, S., Hou, H., Harnisch, F., Patil, S.A., Carmona-Martinez, A.A., Agarwal, S., Zhang, Y., Sinha-Ray, S., Yarin, A.L., Greiner, A., Schröder, U., 2011. Electrospun and solution blown three-dimensional carbon fiber nonwovens for application as electrodes in microbial fuel cells. Energy Environ. Sci. 4, 1417-1421.

Cheng, S., Kiely, P., Logan, B., 2011. Pre-acclimation of a wastewater inoculum to cellulose in an aqueous-cathode MEC improves power generation in air-cathode MFCs. Bioresour. Technol. 102, 367-371.

Erable, B., Roncato, M., Achouak, W., Bergel, A., 2009. Sampling natural biofilms: a new route to build efficient microbial anodes. Environ. Sci. Technol. 43, 31943199.

Fan, Y., Hu, H., Liu, H., 2007. Sustainable power generation in microbial fuel cells using bicarbonate buffer and proton transfer mechanisms. Environ. Sci. Technol. $41,8154-8158$

Finster, K., Bak, F. Pfennig, N., 1994. Desulfuromonas acetexigens sp. nov., a dissimilatory sulfur-reducing eubacterium from anoxic freshwater sediments. Arch. Microbiol. 161, 328-332.

Fricke, K., Harnisch, F., Schroder, U., 2008. On the use of cyclic voltammetry for the study of anodic electron transfer in microbial fuel cells. Energy Environ. Sci. 1, 144-147.

Gil, G., Chang, I., Kim, B.H., Kim, M., Jang, J.-K., Park, H.S., Kimet, H.J., 2003. Operational parameters affecting the performance of a mediator-less microbial fuel cell. Biosens. Bioelectron. 18, 327-334.

Haichar, F.E.Z., Marol, C., Berge, O., Rangel-Castro, J.I., Prosser, J.I., Balesdent, J., Heulin, T., Achouak, W., 2008. Plant host habitat and root exudates shape soil bacterial community structure. ISME J. 2, 1221-1230. 
Harnisch, F., Freguia, S., 2012. A basic tutorial on cyclic voltammetry for the investigation of electroactive microbial biofilms. Chem. Asian J. 7, 466-475.

Harnisch, F., Koch, C., Patil, S.A., Hüsbschmann, T., Müller, S., Schröder, U., 2011. Revealing the electrochemically driven selection in natural community derived microbial biofilms using flow-cytometry. Energy Environ. Sci. 4, 1265-1267.

He, Z., Huang, Y., Manohar, A.K., Mansfeld, F., 2008. Effect of electrolyte pH on the rate of the anodic and cathodic reactions in an air-cathode microbial fuel cell. Bioelectrochemistry 74, 78-82.

Huang, L., Logan, B., 2008a. Electricity generation and treatment of paper recycling wastewater using a microbial fuel cell. Appl. Microbiol. Biotechnol. 80, 349-355.

Huang, L., Logan, B., 2008b. Electricity production from xylose in fed-batch and continuous-flow microbial fuel cells. Appl. Microbiol. Biotechnol. 80, 655-664.

Jadhav, G., Ghangrekar, M., 2009. Performance of microbial fuel cell subjected to variation in $\mathrm{pH}$, temperature, external load and substrate concentration. Bioresour. Technol. 100, 717-723.

Kiely, P.D., Call, D.F., Yates, M.D., Regan, J.M., Logan, B.E., 2011. Anodic biofilms in microbial fuel cells harbor low numbers of higher-power-producing bacteria than abundant genera. Appl. Microbiol. Biotechnol. 88, 371-380.

Kim, J.R., Min, B., Logan, B.E., 2005. Evaluation of procedures to acclimate a microbial fuel cell for electricity production. Appl. Microbiol. Biotechnol. 68, 23-30.

Kim, B.H., Chang, I.S., Gadd, G.M., 2007. Challenges in microbial fuel cell development and operation. Appl. Microbiol. Biotechnol. 76, 485-494.

Liu, Y., Harnisch, F., Fricke, K., Sietmann, R., Schröder, U., 2008. Improvement of the anodic bioelectrocatalytic activity of mixed culture biofilms by a simple consecutive electrochemical selection procedure. Biosens. Bioelectron. 24, 1006-1011.

Liu, Y., Harnisch, F., Fricke, K., Schöder, U., Ciment, V., Feliu, J.M., 2010. The study of electrochemically active microbial biofilms on different carbon-based anode materials in microbial fuel cells. Biosens. Bioelectron. 25, 2167-2171.

Logan, B., 2009. Exoelectrogenic bacteria that power microbial fuel cells. Nat. Rev. 7. 375-381.

Marsili, E., Rollefson, J.B., Baron, D.B., Hozalski, R.M., Bond, D.R., 2008. Microbial biofilm voltammetry: direct electrochemical characterization of catalytic electrode-attached biofilms. Appl. Environ. Microbiol. 74, 7329-7337.
Mathuriya, A.S., Sharma, V.N., 2009. Bioelectricity production from paper industry waste using a microbial fuel cell by Clostridium species. J. Biochem. Technol. 1, $49-52$.

Muyzer, G., De Waal, E.C., Uitterlinden, A.G., 1993. Profiling of complex microbial populations by denaturing gradient gel electrophoresis analysis of polymerase chain reaction-amplified genes coding for $16 \mathrm{~S}$ rRNA. Appl. Environ. Microbiol. 59, 695-700.

Pant, D., Bogaert, G.V., Diels, L., Vanbroekhoven, K., 2009. A review of the substrates used in microbial fuel cells (MFCs) for sustainable energy production. Bioresour. Technol. 101, 1533-1543.

Pocaznoi, D., Erable, B., Delia, M., Bergel, A., 2012. Ultra microelectrodes increase the current density provided by electroactive biofilms by improving their electron transport ability. Energy Environ. Sci. 5, 5287-5296.

Puig, S., Serra, M., Coma, M., Cabré, M., Balaquer, M.D., Colprim, J., 2010. Effect of pH on nutrient dynamics and electricity production using microbial fuel cells. Bioresour. Technol. 101, 9594-9599.

Rabaey, K., Boon, N., Siciliano, S.D., Verhaege, M., Verstraete, W., 2004. Biofuel cells select for microbial consortia that self-mediate electron transfer. Appl. Environ. Microbiol. 70, 5376-5382.

Rozendal, R.A., Sleutels, T., Hamelers, H., Buisman, C.J.N., 2008. Effect of the type of ion exchange membrane on performance, ion transport, and $\mathrm{pH}$ in biocatalysed electrolysis of wastewater. Water Sci. Technol. 57, 1757-1762.

Srikanth, S., Mohan, S.V., Sarma, P., 2010. Positive anodic poised potential regulates microbial fuel cell performance with the function of open and closed circuitry. Bioresour. Technol. 101, 5337-5344.

Torres, C.I., Krajmalnik-Brown, R., Parameswaran, P., Marcus, A.K., Wanger, G., Gorby, Y.A., Rittmann, B.E., 2009. Selecting anode-respiring bacteria based on anode potential: phylogenetic, electrochemical, and microscopic characterization. Environ. Sci. Technol. 43, 9519-9524.

Yi, H. Nevin, K. . Kim, B.C. Franks, A.E. Klimes, A Tender, L.M Lovley, D R, 2009. Selection of a variant of Geobacter sulfurreducens with enhanced capacity for current production in microbial fuel cells. Biosens. Bioelectron. 24, 3498-3503.

Wang, A., Sun, D., Ren, N., Liu, C., Liu, W., Logan, B., Wu, W., 2010. A rapid selection strategy for an anodophilic consortium for microbial fuel cells. Bioresour. Technol. 101, 5733-5735.

Zhuang, L., Zhou, S., Li, Y., Yuan, Y., 2010. Enhanced performance of air-cathode twochamber microbial fuel cells with high-pH anode and low-pH cathode. Bioresour. Technol. 101, 3514-3519. 